\title{
An Inherited Kidney Disease of Mice Resembling Human Nephronophthisis
}

\author{
MARY F. LYON and E. V. HULSE \\ From the M.R.C. Radiobiology Unit, Harwell, Didcot, Berkshire
}

This paper describes an inherited kidney disease which arose spontaneously in an inbred strain of mice, and appears to be due to a single autosomal recessive gene which has been given the name and symbol kidney disease, $k d$. Several types of hereditary kidney diseases are known in man, but the number of such diseases available for study in laboratory animals is still few, and it is possible that investigation of the disease described here may help to elucidate human inherited renal diseases. In particular, it resembles nephronophthisis, a genetically controlled disease in man characterized clinically by polyuria, polydipsia, and loss of renal concentrating ability, and pathologically by both tubular atrophy and dilatation. We have not undertaken electron microscopy, microdissection or chemical investigations, other than the simplest tests, and would be glad to provide animals from the stock to those interested in investigating the condition further.

\section{Origin and Clinical Description}

The first affected animals were found among the offspring of closely related pairs in the CBA/CaH inbred strain. The animals were first noticed to be losing weight, at the age of a few months. They became very thin and hunched, and their urine became colourless. At necropsy the kidneys were pale, contracted, and granular.

At first, mice were classified as affected or not on the basis of the colour of the urine and the macroscopical appearance of the kidneys. Every two weeks from about $3 \frac{1}{2}$ months of age the colour of a urine specimen from each mouse was noted. After three consecutive specimens had been colourless, or when the mouse had reached the age of 6 months, whichever was the earlier, it was killed and the kidneys were inspected.

Later, this method was replaced by tests of urinary protein using Hema-Combistix reagent strips (Ames). Proteinuria is normal in mice, the quantity varying with a number of factors including diet (Bernstein, 1966) and urine from normal CBA/CaH mice gave a Hema-

Received 24 August 1970.
Combistix rating of 'trace' or ' + '. Mice classified as affected from the colour of their urine scored ' +++ ' or ' ++++ ' for urinary protein (the latter being the maximum for the method), those classified as not affected scored 'trace' or ' + ', and the ambiguous ' ++ ' category was rare (only 2 out of 115 tested animals). Tests at various ages showed that the increase in urinary protein in animals which developed colourless urine was first detectable by Hema-Combistix at about 10 weeks of age, and, also, that any animals which scored ' ++ ' at first would later give an unambiguous result. Thereafter, mice were classified by testing urine specimens with Hema-Combistix at intervals of 2 weeks beginning at 11 weeks of age or more. Two unambiguous tests were considered sufficient to classify a mouse as normal or affected.

Affected animals were normal in size and general health from birth until well after the onset of the disease process in their kidneys. They began to drink excessively when aged about 3 to 4 months. Loss of weight usually became obvious at about 4 to 6 months, and became progressively worse until death, usually at 5 to 7 months. Occasionally mice lived longer and one survived to 11 months.

\section{Genetic Investigations}

Both males and females were fertile and females reared their litters normally, until the disease progressed to the stage of noticeable loss of weight, when first rearing ability, and then fertility were lost. Males appeared to retain fertility until shortly before death, but very few affected pairs produced more than three litters.

Single factor segregation. The data in Table I show that the disease is inherited as though due to an autosomal recessive gene with complete penetrance and normal viability.

Some matings were made within the CBA subline in which the disease was first detected, and others with animals obtained after outcrossing $k d k d$ animals from the CBA subline to normal animals of unrelated strains. The outcross progeny showed that the viability and penetrance were not affected by outcrossing. The age of onset of the disease, however, was a few weeks later among the outcross animals, whether judged by increase in urinary protein, or by loss of colour of urine. 
TABLE I

SINGLE FACTOR SEGREGATION OF $k d$

\begin{tabular}{|c|c|c|c|c|}
\hline Cross & Parents & & $\underset{+}{\text { Offs }}$ & $\underset{k d}{i n g}$ \\
\hline $\begin{array}{l}1 \\
2 \\
3 \\
4 \\
5\end{array}$ & $\begin{array}{l}+k d \times+k d \\
+k d \times+k d \\
+k d \times k d k d \\
+k d \times k d k d \\
k d k d \times k d k d\end{array}$ & $\begin{array}{l}\text { Obs. } \\
\text { Exp. } \\
\text { Obs. } \\
\text { Exp. } \\
\text { Obs. } \\
\text { Exp. } \\
\text { Obs. } \\
\text { Exp. } \\
\text { - }\end{array}$ & $\begin{array}{l}64 \\
59 \cdot 25 \\
176 \\
176 \cdot 25 \\
25 \\
27 \cdot 5 \\
50 \\
45 \cdot 0 \\
-\end{array}$ & $\begin{array}{l}15 \\
19 \cdot 75 \\
59 \\
58 \cdot 75 \\
30 \\
27 \cdot 5 \\
40 \\
45 \cdot 0 \\
63\end{array}$ \\
\hline
\end{tabular}

Crosses 1, 3, and 5, CBA/CaH background, urine colour classification.

Crosses 2 and 4 , outcross progeny, HemaCombistix classification.

Linkage relations. The results of linkage tests of $k d$ with various marker genes are shown in Table II. In an attempt to confirm or disprove the apparent linkage with waltzer, $v$, tests were made with another marker in the same linkage group, grizzled, $g r$. Repulsion intercrosses and backcrosses both indicated significant linkage of $k d$ and $g r$ (Table III), though there was a conspicuous deficiency of grizzled homozygotes which are

TABLE II

RESULTS OF LINKAGE TESTS WITH $k d$

\begin{tabular}{|c|c|c|c|c|c|c|c|c|}
\hline $\begin{array}{c}\text { Linkage } \\
\text { Group }\end{array}$ & Marker & ++ & $\begin{array}{r}\text { Offs } \\
+k d\end{array}$ & $\begin{array}{l}\text { ing } \\
m+\end{array}$ & $m k d$ & $x^{2}$ & R.F. & S.E. \\
\hline $\begin{array}{c}\text { A: Reces } \\
\text { V } \\
\text { VIII } \\
\text { I } \\
\text { II } \\
\text { III } \\
\text { XI } \\
\text { XIII } \\
\text { XIII } \\
\text { X } \\
\text { XII }\end{array}$ & $\begin{array}{l}\text { ive mark } \\
\text { a } \\
\text { b } \\
\text { cch } \\
\text { se } \\
\text { s } \\
\text { wa-1 } \\
\text { fz } \\
\text { ln } \\
\text { v } \\
\text { ep }\end{array}$ & $\begin{array}{l}s(m) \\
70 \\
93 \\
84 \\
87 \\
99 \\
92 \\
63 \\
68 \\
70 \\
66\end{array}$ & $\begin{array}{l}13 \\
24 \\
22 \\
26 \\
27 \\
28 \\
16 \\
17 \\
20 \\
15\end{array}$ & $\begin{array}{l}23 \\
30 \\
38 \\
37 \\
24 \\
31 \\
29 \\
24 \\
22 \\
25\end{array}$ & $\begin{array}{l}7 \\
7 \\
9 \\
5 \\
4 \\
3 \\
4 \\
3 \\
0 \\
5\end{array}$ & $\begin{array}{l}0.61 \\
0.03 \\
0.16 \\
2.33 \\
0.23 \\
2.43 \\
1.29 \\
0.78 \\
3.11 \\
0.08\end{array}$ & $\begin{array}{l}55 \cdot 5 \\
49 \cdot 0 \\
47 \cdot 5 \\
40 \cdot 8 \\
47 \cdot 1 \\
40 \cdot 6 \\
42.0 \\
43 \cdot 8 \\
37.5 \\
48 \cdot 0\end{array}$ & $\begin{array}{l}7 \cdot 0 \\
6 \cdot 0 \\
6 \cdot 1 \\
6 \cdot 0 \\
6 \cdot 0 \\
6 \cdot 0 \\
7 \cdot 1 \\
7 \cdot 1 \\
7 \cdot 1 \\
7 \cdot 1\end{array}$ \\
\hline
\end{tabular}

\begin{tabular}{|c|c|c|c|c|c|c|c|c|}
\hline $\begin{array}{l}\text { Linkage } \\
\text { Group }\end{array}$ & Marker & $M+$ & Mkd & ++ & $+k d$ & $x^{2}$ & R.F. & S.E. \\
\hline $\begin{array}{l}\text { B: Domir } \\
\text { VI } \\
\text { XI } \\
\text { IX } \\
\text { XVI } \\
\text { VIII } \\
\text { V }\end{array}$ & $\begin{array}{l}\text { ant mark } \\
\mathrm{Ca} \\
\mathrm{Mi}^{\mathrm{wh}} \\
\mathrm{T} \\
\mathrm{Va} \\
\mathrm{Re} \\
\mathrm{Ra}\end{array}$ & $\begin{array}{l}\text { rs }(M \\
14 \\
12 \\
12 \\
11 \\
20 \\
15\end{array}$ & $\begin{array}{r}13 \\
10 \\
8 \\
15 \\
16 \\
13\end{array}$ & $\begin{array}{l}21 \\
11 \\
13 \\
23 \\
19 \\
19\end{array}$ & $\begin{array}{r}20 \\
16 \\
9 \\
18 \\
19 \\
20\end{array}$ & $\begin{array}{l}0.00 \\
1.00 \\
0.00 \\
1.21 \\
0.22 \\
0.13\end{array}$ & $\begin{array}{l}50 \cdot 0 \\
42 \cdot 9 \\
50 \cdot 0 \\
56 \cdot 7 \\
47 \cdot 3 \\
47 \cdot 8\end{array}$ & $\begin{array}{l}6.0 \\
7.1 \\
7 \cdot 7 \\
6 \cdot 0 \\
5.8 \\
6.1\end{array}$ \\
\hline
\end{tabular}

known to have reduced viability (Bloom and Falconer, 1966). Similarly, the coupling backcross indicated linkage, though with a deficiency of $k d k d$ as well as $g r g r$, which would be expected if they were indeed linked. However, the coupling intercrosses gave unexpected results, again with gross deficiencies of $k d$ and $g r$, but with more crossovers than would have been expected on the basis of the results from the other types of cross. The reason for these anomalous results is not known, but in view of the reasonably consistent results from the other crosses with $g r$ and those with $v$, the linkage has been considered to be a real one. The re-
TABLE III

RESULTS OF LINKAGE TESTS BETWEEN $g r$ and $k d$

\begin{tabular}{c|c|rrrr}
\hline \multirow{2}{*}{ Cross } & Parents & \multicolumn{4}{|c}{ Offspring } \\
& & $++g r+$ & $+k d$ & $g r k d$ \\
\hline 1 & $g r+|+k d \times g r+|+k d$ & 103 & 29 & 55 & 1 \\
2 & $g r+\mid+k d \times g r k d / g r k d$ & 2 & 3 & 7 & -6 \\
3 & $++\mid g r k d \times g r k d / g r k d$ & 15 & 2 & 2 & 6 \\
4 & $++|g r k d \times+| g r k d$ & 62 & 13 & 6 & 2 \\
\hline
\end{tabular}

\begin{tabular}{|c|c|c|c|c|c|c|}
\hline Cross & $\mathbf{p}$ & & $\mathbf{u}$ & \multicolumn{3}{|c|}{$\begin{array}{l}\text { Goodness-of-fit } \\
x^{2} \text { d.f. } p\end{array}$} \\
\hline $\begin{array}{l}1 \\
2 \\
3 \\
4\end{array}$ & $\begin{array}{l}0 \cdot 168 \pm 0.087 \\
0 \cdot 167 \pm 0 \cdot 108 \\
0 \cdot 160 \pm 0 \cdot 073 \\
0.376 \pm 0 \cdot 239 *\end{array}$ & $\begin{array}{l}1 \cdot 76 \\
3 \cdot 00 \\
2 \cdot 125 \\
1 \cdot 51\end{array}$ & $\begin{array}{l} \pm 0.61 \\
\pm 2.00 \\
\pm 0.91 \\
\pm 2.33^{*}\end{array}$ & $\begin{array}{l}0 \cdot 450 \\
0 \cdot 800 \\
0 \cdot 709 \\
9 \cdot 71\end{array}$ & $\begin{array}{l}1 \\
1 \\
1 \\
1\end{array}$ & $\begin{array}{l}0.50 \\
0.37 \\
0.40 \\
0.0018\end{array}$ \\
\hline Overall & $0.241 \pm 0.057^{*}$ & $1 \cdot 78$ & $\pm 0.55^{*}$ & $19 \cdot 88$ & 10 & 0.030 \\
\hline $\begin{array}{l}\text { Overall } \\
\text { (omitting } \\
\text { last line) }\end{array}$ & $0.164 \pm 0.050$ & 1.89 & \pm 0.47 & 2.51 & 7 & 0.926 \\
\hline
\end{tabular}

Maximum-likelihood estimates of $p, u$ are shown above.

$\mathrm{p}=$ recombination fraction.

$\mathbf{u}=$ viability of '+' phenotypes relative to $\mathrm{gr}$.

The estimates of $p$ and $u$, jointly, do not differ significantly between matings, either when the last mating is included $[F(6,10)=0.535$; $p=0.77]$ or when it is omitted $\left[x_{4}^{2}=0.979 ; p=0.913\right]$.

combination has been calculated both including and excluding the coupling intercrosses, but the latter value of $16.4 \pm 5.0$ per cent is probably the more suitable one to use.

\section{Pathological Investigations}

Methods. Some of the mice used in the pathological investigations were allowed to die spontaneously. Others, known to be homozygous, were killed, using ether anaesthesia, at ages ranging from 4 to 43 weeks. In most cases blood was taken by cardiac puncture as the mouse was dying, in order to determine the packed cell volume, using a microchaematocrit, and the blood urea, using the Urastrat (Warner) method for whole blood as described by Baron and Hughes (1965).

Both kidneys, the spleen, the heart, and either liver or lung were taken routinely for histological examination. Occasionally other organs of normal appearance were taken to exclude possible histological abnormalities. Tissues were fixed in formol saline and sections routinely stained with haematoxylin and eosin. Perl's stain for iron and the periodic acid-Schiff reaction were used on selected sections

When sufficient urine was available the whole of the Hema-Combistix range of tests were used, viz : protein, blood, glucose, and $\mathrm{pH}$. If the amount collected was small the tests for protein and blood (because of the haemosiderin deposits) were given priority. Specific gravity was measured with Microcaps (Drummond) using a recently devised and tested method (Mole and Watts, 1971).

Post-mortem appearances. Mice with the fully developed disease had pale viscera and were obviously anaemic. The kidneys were putty-coloured, contracted, and very granular and their pelves were often slightly 
larger than usual, due to contraction of the kidney parenchyma. The heart was usually enlarged and occasionally there was white streaking of some myocardial fibres. Occasionally a clear pleural effusion was present. The spleen tended to be small.

Histology. The histological appearances of the kidney in the fully developed case are shown in Fig. 1, 2, and 3. Depressed scars where tubules were atrophied alternated with areas where many of the tubules were dilated, up to five times normal (Fig. 1 and 2). In the scarred areas the glomeruli were sclerotic (Fig. 3), usually through periglomerular fibrosis and capsular thickening, but in some glomeruli part of the tuft was hyalinized. The tubules were narrowed and atrophied and in some places their basement membranes were slightly thickened. In most cases interstitial fibrosis was not a prominent

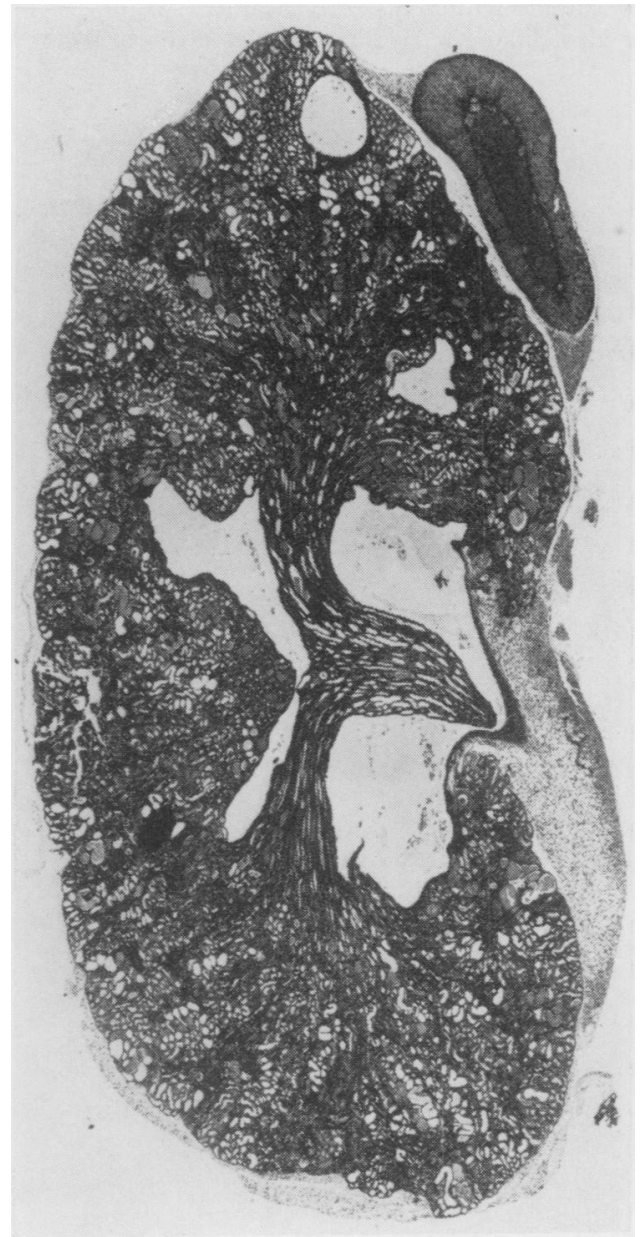

FIG. 1. Low power view of a longitudinal section of a severely affected kidney with the adrenal attached. The surface of the kidney is irregular due to areas of scarring alternating with areas of tubular dilatation. Small cysts are present. (H. and E. $\times 14$.)

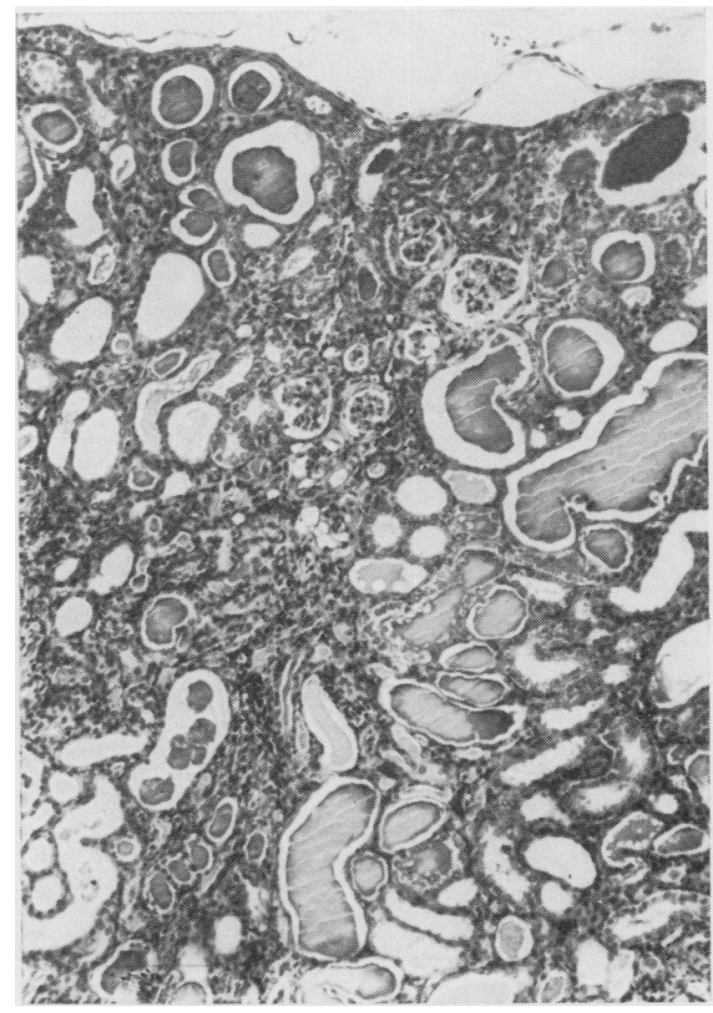

FIG. 2. Severely affected kidney showing a narrow scar with atrophied tubules between two areas of dilated tubules, many containing eosinophilic colloid casts. (H. and E. $\times$ 105.)

feature but on occasion it did occur. Small cysts lined with thin, attenuated cells were not uncommon in both cortex and medulla (Fig. 1) but were not seen in every case.

Outside the scars many of the tubules, sometimes the majority, whether normal sized or dilated, contained eosinophilic colloid casts. The casts were devoid of cells except very occasionally when the small amount of cellular debris included degenerate granulocytes. The casts extended from the first convoluted tubules to the collecting tubules in the papilla where they were occasionally seen to be excreted into the kidney pelvis. Apart from the tubular casts the papilla was normal. A few glomeruli in the unscarred areas appeared normal but most were sclerotic.

Haemosiderin was common, particularly in scarred areas. Some of it was clearly within cells of proximal convoluted tubules but, in the areas of scarring, denser, circumscribed, and more intensely staining deposits appeared to be in the interstitial tissues. Small foci of lymphocytes or plasma cells were occasionally seen in the interstitial tissue of severely affected kidneys.

The spleen in severely affected mice was nearly always slightly atrophic and packed with haemosiderin. The white streaks in the myocardium were found to be due to granular degeneration of individual muscle fibres such 


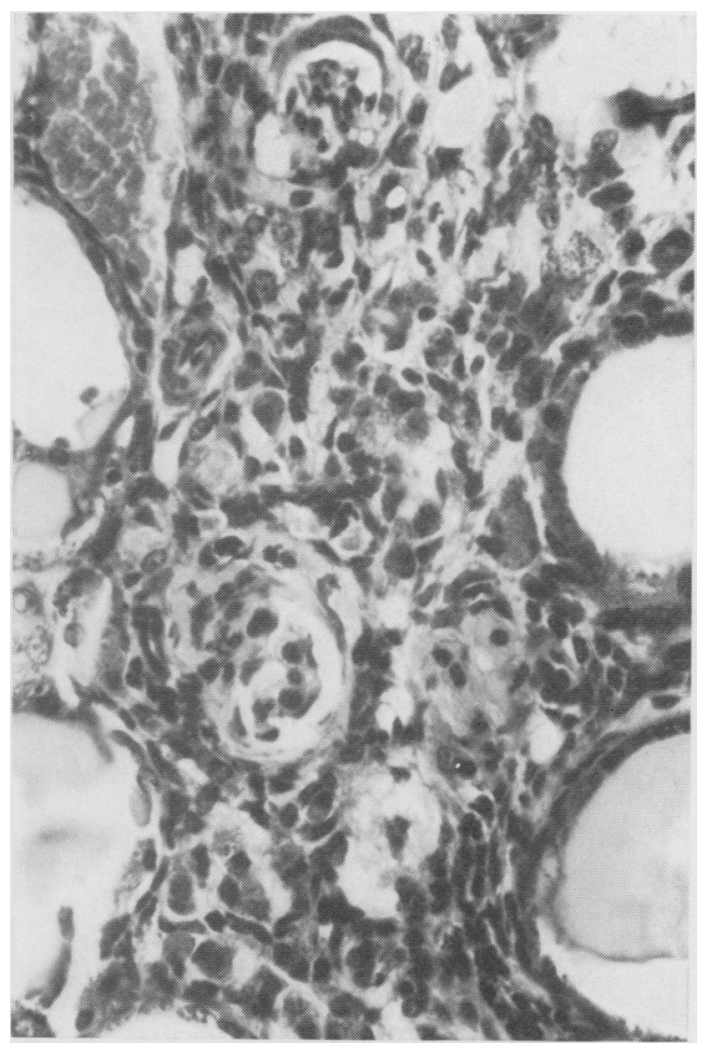

Fig. 3. Higher power of a linear scar showing degenerate glomeruli. Dilated tubules, some of which contain colloid, are present either side of the scar. (H and E. $\times 425$.)

as is seen in elderly CBA mice (de Vries and Vos, 1959; Sokoloff, 1965).

Development of disease. The severity of the kidney lesions at different ages and the accompanying

TABLE IV

RELATION BETWEEN AGE, KIDNEY HISTOLOGY, BLOOD UREA, AND PACKED CELL VOLUME IN' $k d k d$ AND CBA MICE

\begin{tabular}{|c|c|c|c|c|c|c|c|c|}
\hline \multirow{2}{*}{$\begin{array}{l}\text { Strain } \\
k d k d\end{array}$} & \multirow{2}{*}{$\begin{array}{c}\begin{array}{c}\text { Age } \\
\text { Range } \\
\text { (wk.) }\end{array} \\
4-9 \\
10-14 \\
17-28 \\
29-43\end{array}$} & \multirow{2}{*}{$\begin{array}{c}\begin{array}{c}\text { Total } \\
\text { No. of } \\
\text { Mice }\end{array} \\
13 \\
10 \\
15 \\
13\end{array}$} & \multicolumn{4}{|c|}{$\begin{array}{l}\text { No. of Mice at } \\
\text { Various } \\
\text { Histological } \\
\text { Stages* } \\
\text { i ii iii iv }\end{array}$} & $\begin{array}{c}\text { Blood Urea } \\
\text { (mg./100 ml.) } \\
\text { mean } \\
(\text { ranget })\end{array}$ & $\begin{array}{l}\text { PCV } \\
\% \\
\text { mean } \\
\text { (S.E.) }\end{array}$ \\
\hline & & & $\begin{array}{r}13 \\
2 \\
1 \\
0\end{array}$ & $\begin{array}{l}0 \\
8 \\
0 \\
0\end{array}$ & $\begin{array}{r}0 \\
0 \\
14 \\
1\end{array}$ & $\begin{array}{r}0 \\
0 \\
0 \\
12\end{array}$ & $\begin{array}{c}51(40-80) \\
46(40-80) \\
77(40-120) \\
>212(120->300)\end{array}$ & $\begin{array}{l}47(1) \\
50(1) \\
48(1) \\
36(3)\end{array}$ \\
\hline CBA & $\begin{array}{l}10 \\
40\end{array}$ & $\begin{array}{l}11 \\
10\end{array}$ & $\begin{array}{l}11 \\
10\end{array}$ & $\begin{array}{l}0 \\
0\end{array}$ & $\begin{array}{l}0 \\
0\end{array}$ & $\begin{array}{l}0 \\
0\end{array}$ & $\begin{array}{l}50(40-60) \\
51(40-60)\end{array}$ & $\begin{array}{l}51(1) \\
49(1)\end{array}$ \\
\hline
\end{tabular}

* Histological stages: (i) no visible abnormality; (ii) a small number of colloid casts; (iii) numerous casts but little scarring; (iv) fully developed disease.

+ As the method allowed only 7 readings $(40,60,80,120,180,240$, and $300 \mathrm{mg} . / 100 \mathrm{ml}$.), a range is quoted rather than a standard error. changes in the blood urea and packed cell volume are given in Table IV.

Kidneys. The earliest histological abnormalities were seen when the mice were aged 10 to 14 weeks, when a small number of tubules were distended with colloid casts particularly in the inner half of the cortex (Fig. 4). The more distal parts of the nephron, including the collecting tubules, could also contain casts at this stage. In a few instances Bowman's space was distended with colloid as well as the proximal convoluted tubule. The epithelium of a few proximal convoluted tubules in the vicinity of tubules containing casts showed severe hyaline droplet change. Occasionally a few atrophied tubules were seen, always near to those showing casts or hyaline droplet change and often near to a glomerulus.

At 17 to 28 weeks colloid casts were nearly always very numerous and some of the affected tubules were dilated. A few tubules without casts in the outer part of the cortex were also dilated. Hyaline droplet changes were very

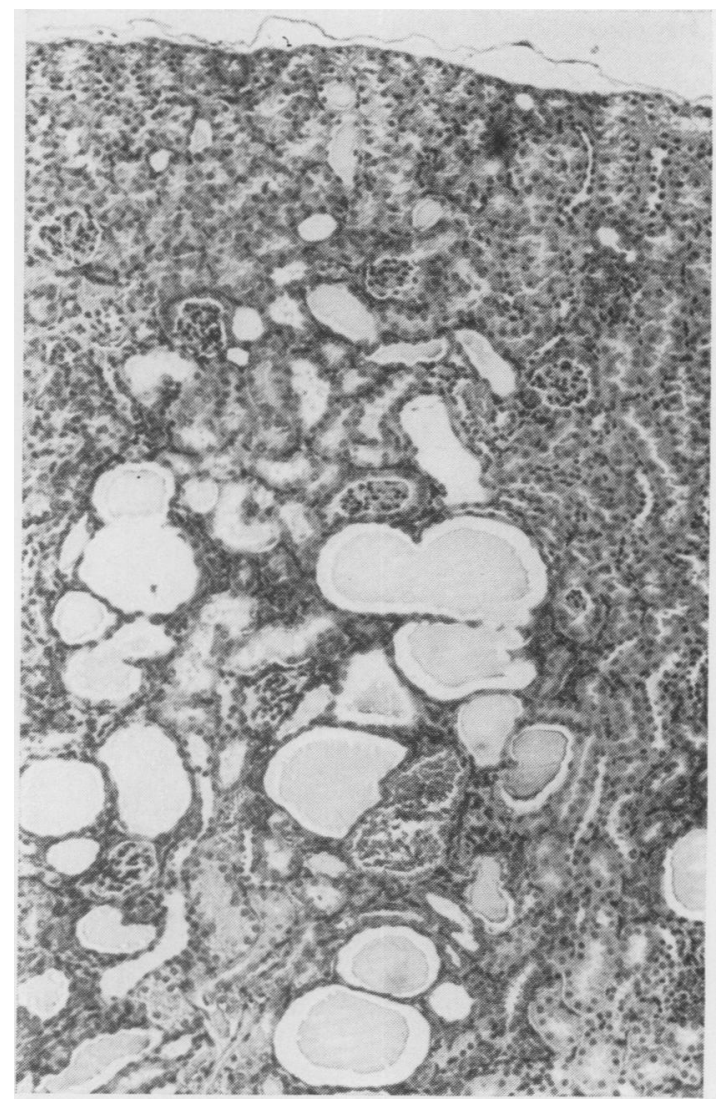

FIG. 4. Section of a kidney at an early stage of the disease showing a few dilated tubules containing casts among apparently normal tubules and glomeruli. This kidney is from a male mouse, and the cuboidal lining of the glomerular capsules commonly found in normal adult males is present in many glomeruli, including one adjacent to a dilated tubule. (H. and E. $\times 110$.) 
rare. Atrophied tubules were more frequently seen, particularly in relation to the small amount of linear, radial scarring. Relatively mild sclerotic changes were seen in some glomeruli.

In older mice the histological appearances were those of the fully developed disease already described. Cysts were seen only in kidneys with very advanced lesions.

Even in the earliest stages a little haemosiderin was present in the cells of the proximal convoluted tubules, sometimes associated with casts and sometimes apparently proximal to the casts. In more advanced cases some of the haemosiderin appeared to be in the interstitial tissues, but with periodic acid-Schiff staining such deposits were usually found to be surrounded by a basement membrane and intermediate stages between tubular and apparently interstitial deposits were observed. Thus tubules with haemosiderin in their epithelium could atrophy so severely that only a few closely packed epithelial cells filled with iron remained.

Spleen. The presence of haemosiderin in the red pulp is not considered abnormal, particularly in older mice (Dunn, 1954). At 10 weeks the deposits in the spleens of normal CBA mice were relatively small but at 40 weeks over twice as much was present. In $k d k d$ mice the amount of haemosiderin in the spleen did not exceed normal unless there were at least a moderate number of casts in the tubules. When the kidneys were severely affected the amount of haemosiderin in the spleen was usually grossly in excess of normal.

Blood (Table IV). Blood urea in normal CBA mice was about $50 \mathrm{mg} . / 100 \mathrm{ml}$. Three $k d k d$ mice, aged 9, 10, and 18 weeks, with histologically normal kidneys, had a blood urea of $80 \mathrm{mg} . / 100 \mathrm{ml}$. Otherwise the blood urea remained within normal limits until a moderate number of casts were present, at which stage over half of the mice examined had a blood urea of $80 \mathrm{mg}$. or $120 \mathrm{mg} . / 100 \mathrm{ml}$. When the kidney disease was histologically severe the blood urea was always considerably above normal and in a quarter of the mice examined was at least $300 \mathrm{mg}$./ $100 \mathrm{ml}$.

The packed cell volume remained normal until the kidney disease was advanced. None of the mice with severely affected kidneys had a PCV greater than $40 \%$ and the lowest, $17 \%$, was in a 38-week-old mouse which had a blood urea of over $300 \mathrm{mg} . / 100 \mathrm{ml}$.

Urine (Table IV). The degree of albuminuria at various ages has already been considered in the clinical description of the condition. Only a very few $k d k d$ mice were found to be passing urine which gave a positive reaction for blood (haemolysed or unhaemolysed) and a maximum rating of ' +++ ' was never obtained. Urine from normal CBA mice never gave a positive reaction. The $p \mathrm{H}$ of the urine of CBA and $k d k d$ mice ranged from 5 to 6 , and in both cases the test for glucose was consistently negative.

The specific gravity of the urine of normal CBA mice ranged from 1.030 to 1.080 , with a mean of about 1.060 , and that of young $k d k d$ mice had a similar range and mean. After 14 weeks the mean obtained from $k d k d$ mice began to fall, and from 20 weeks onwards individual specific gravities were almost always below 1.030 and frequently below 1.010.

\section{Discussion}

There are various mutant genes of the mouse which interfere with normal morphological development of the kidney, its blood vessels, or ureter, and thereby lead to absence or malformation of the kidney, or hydronephrosis. There are few genes, however, which result, as does $k d$, in abnormal function of an apparently normally developed kidney. Examples include the autoimmune kidney disease of NZB/B1 mice (Helyer and Howie, 1963), and the polyarteritis nodosa-like kidney lesion of mice of strain PN (Wigley and Couchman, 1966). The kidney disease produced by the LCM virus, which resembles that produced by autoimmune disease, superficially appears to be inherited in that the virus is transmitted from parent to offspring across the placenta (Hotchin and Collins, 1964; Kajima and Pollard, 1969). Histologically, the disease produced by $k d$ differs from all of these, and it appears to be genetically distinct.

Nature of pathological changes. The histological changes in $k d k d$ mice are very similar to those of the chronic nephritis frequently encountered in elderly rats (Snell, 1967) except that haemosiderin deposits do not occur in the rat disease. In some strains of rats proliferation of tubular epithelial cells occurs early in the disease (Andrew and Pruett, 1957; Kennedy, 1957), and it was suggested (Kennedy, 1957) that this led to tubular obstruction. However, this proliferation hardly ever occurs in other strains of rats (Gray, 1963). In $k d k d$ mice the tubules were never excessively cellular and the few mitoses observed were in tubules already containing casts. Alternatively it has been suggested that chronic nephritis in rats is caused by excessive excretion or faulty absorption of protein leading to cast formation and partial or complete blockage of the tubules (Saxton and Kimball, 1941; Gray, 1963).

In $k d k d$ mice the casts, the hyaline droplet degeneration of the tubules, and the occasional atrophied tubule all appeared at about the same time. Ordinary histological methods did not provide any indication of how the cast formation and the tubular atrophy were related or whether they ever occurred in the same nephron. Presumably microdissection would provide further information on this aspect of the pathogenesis.

Haemosiderin appeared early in both dilated and 
atrophied tubules. There was no evidence that haemolysis occurred at any stage; the supernatant serum of the haematocrits was always normal in colour and on only few occasions did the urine give a positive test for blood. Haemosiderin is deposited in the tubular epithelium of the mouse when the haemosiderin content of the blood rises above the glomerular threshold (Dunn, 1949) and this threshold is lowered in the presence of patchy chronic nephritis (Cappell, 1930).

Similarities with human diseases. Three genetically controlled types of human kidney disease show sufficient similarity to $k d k d$ to be considered, viz. Alport's hereditary haematuric nephritis, congenital familial nephrosis, and nephronophthisis (Harris, 1967; McGrory, Shibuya, and Worthen 1966; Perkoff, 1964).

Alport's disease. Some cases show histological changes which resemble chronic pyelonephritis and are, therefore, not unlike those seen in kdkd mice, but the majority of cases are more like chronic glomerulonephritis (Perkoff, 1964; Heptinstall, 1967). Episodic haematuria, which is an important part of Alport's disease, was virtually absent in $k d k d$ mice. The nerve deafness which is frequently found in Alport's disease and the ophthalmic defects which can occur were both absent in $k d k d$ mice. Genetically the diseases are quite different. Not only is Alport's disease inherited as an autosomal dominant while $k d$ is a recessive, but Alport's disease has the peculiarities that males are more severely affected than females and that affected females produce more than the expected $50 \%$ of affected offspring, while the inheritance of $k d$ is normal Mendelian.

Infantile nephrosis. This disease is inherited as an autosomal recessive (Norio, 1966), and histologically, dilated tubules often containing casts have been reported in many instances (Giles et al., 1957; Hallmann and Hjelt, 1959; Worthen, Vernier, and Good, 1959; McCrory et al., 1966). However, typical nephrotic oedema always occurs in infantile nephrosis and oedema was never seen at any stage of the disease in $k d k d$ mice, even when the affected mice were encouraged to drink excessively by giving them milk instead of food and water. In addition the age of onset in infantile nephrosis is different from that of $k d k d$ since the former is often present at birth or very shortly afterwards and at the latest within a few months of birth.

Nephronophthisis. The disease in kdkd mice shows considerable similarities, clinically, genetically, and pathologically to the condition known as nephronophthisis (Fanconi et al., 1951; Royer, 1968). Genetically, this disease is inherited as a typical autosomal recessive. It is extremely rare and Royer (1968) listed only 14 families, but these included three cases of consanguinity. The sexes were affected equally, and the parents were nearly always normal, the only exception being a mild defect of urine concentrating ability in some cases, which may represent a heterozygous expression (Grüttner and Lenz, 1957; Broberger, Winberg, and Zetterström, 1960; Mangos et al., 1964).

Clinically, nephronophthisis resembles $k d k d$ in that there is a definite symptom-free interval after birth; the disease usually becomes apparent between the ages of 2 and 4 years but may appear as late as 7 or 8 . Death occurs about the age of 10 (Royer, 1968). Polyuria and polydipsia are constant findings. Anaemia is common, loss of weight and retardation of growth occur, the blood urea is raised, and the urinary specific gravity is low. All these findings are comparable to those in $k d k d$ mice except that we have not specifically tested for polyuria in the mice, and the onset of the mouse disease is too late to retard growth. In nephronophthisis, albuminuria is often present but never severe. In $k d k d$ mice the degree of albuminuria was consistently increased, but as albuminuria is normal in mice the degree of pathological albuminuria is not as great as might appear from the Hema-Combistix grading.

Pathologically the principal changes in both diseases are in the kidney tubules. In nephronophthisis, as in $k d k d$ mice, the tubules are either atrophied or dilated, the latter often containing colloid and thus giving a thyroid-like appearance (Fanconi et al., 1951; Hackzell and Lundmark, 1958; Hooft, Roels, and Herpol, 1959; Ivemark, Ljungqvist, and Barry, 1960; Sydow and Ranström, 1962). In nephronophthisis the basement membrane of the tubules is often much thickened, whereas in $k d k d$ mice such thickening, if present, is only slight. Interstitial fibrosis tends to be more prominent in nephronophthisis. The glomeruli in nephronophthisis are very similar to those in the fully developed $k d k d$ disease, being sclerosed, hyalinized, and fibrotic, with very few normal glomeruli remaining (Hackzell and Lundmark, 1958; Sydow and Ranström, 1962). Small cysts are sometimes seen in nephronophthisis (Sydow and Ranström, 1962; Royer, 1968), as in kdkd mice. It has been suggested (McCrory et al., 1966) that medullary cystic disease of the kidney (Smith and Graham, 1945) may be related to nephronophthisis. In this 
respect it is of interest to note that in $k d k d$ mice small cysts occurred only in the most advanced stages of the disease. An interstitial infiltration of lymphocytes sometimes seen in $k d k d$ mice can occur in nephronophthisis (Hooft et al., 1959), but there is no counterpart of the haemosiderin deposits seen in $k d k d$.

Thus, though there are some differences between the two diseases, the similarities are sufficiently great for us to consider that $k d k d$ is probably the murine counterpart of human nephronophthisis, and investigations made with the former may throw some light on causes or possible treatments of the human disease. Though it is clear that nephronophthisis involves a tubular defect the nature of this defect is not clear. Further knowledge on this point might help to elucidate renal tubular diseases in general (Seifert, Grüttner, and Lenz, 1960; Perkoff, 1964).

\section{Summary}

An inherited kidney disease, which arose spontaneously in an inbred strain of mice, appears to be due to an autosomal recessive gene which has been given the name and symbol kidney disease, $k d$. This gene is located in linkage group $\mathrm{X}$, and shows about $16.4 \%$ recombination with grizzled $(g r)$. Clinically, the disease was first detectable at about 10 weeks of age by increased proteinuria. This was followed over several weeks by excessive drinking, dilute urine, loss of weight, anaemia, and death in uraemia usually at 5 to 7 months. Pathologically, areas of tubular atrophy alternated with areas of dilated tubules, often containing hyaline casts. The glomeruli were sclerotic in the areas of tubular atrophy and the cells of some of the atrophied tubules contained haemosiderin. Epithelial hyaline droplet change occurred in the earliest stages.

In clinical, genetical, and pathological respects the mouse disease strongly resembled the human inherited kidney disease, nephronophthisis. Breeding stock can be made available for those wishing to investigate the condition further.

We are very grateful to Mr. R. Meredith, who found the first affected animals, to Mr. P. Glenister, Miss L. G. Mizon, and Mr. R. H. Watts for assistance, and to Mr. D. G. Papworth for the calculations in Table III.

\section{REFERENCES}

Andrew, W. and Pruett, D. (1957). Senile changes in the kidneys of Wistar Institute rats. American fournal of Anatomy, 100, 51-69. Baron, D. N. and Hughes, G. (1965). Rapid estimation of urea in whole blood with Urastrat. British Medical fournal, 1, 233-234.

Bernstein, S. E. (1966). Physiological characteristics. In Biology of the Laboratory Mouse, ed. E. L. Green, 2nd ed., pp. 337-350. McGraw-Hill, New York.
Bloom, J. L. and Falconer, D. S. (1966). 'Grizzled', a mutant in linkage group X of the mouse. Genetical Research, 7, 159-167.

Broberger, O., Winberg, J., and Zetterström, R. (1960). Juvenile nephronophthisis Part I: A genetically determined nephropathy with hypotonic polyuria and azotaemia. Acta paediatrica, 49, 470-479.

Cappell, D. F. (1930). The late results of intravenous injection of colloidal iron. Fournal of Pathology and Bacteriology, 33, 175-196.

Dunn, T. B. (1949). Some observations on the normal and pathologic anatomy of the kidney of the mouse. Fournal of the National Cancer Institute, 9, 285-301.

- (1954). Normal and pathologic anatomy of the reticular tissue in laboratory mice, with a classification and discussion of neoplasms. Fournal of the National Cancer Institute, 14, 1281-1433.

Fanconi, G., Hanhart, E., Albertini, A. v., Uthlinger, E., Dolivo, G., and Prader, A. (1951). Die familiäre juvenile Nephronophthise. Helvetica Paediatrica Acta, 6, 1-49.

Giles, H. McC., Pugh, R. C. B., Darmady, E. M., Stranack, F., and Woolf, L. I. (1957). The nephrotic syndrome in early infancy: a report of three cases. Archives of Disease in Childhood, 32, 167180.

Gray, J. E. (1963). Naturally occurring and sulfonamide-induced lesions in rats during a 1-year toxicity study. American fournal of Veterinary Research, 24, 1044-1059.

Grüttner, R. and Lenz, W. (1957). Zur Kenntnis und zur Differentialdiagnose der familiären Nephronophthise in Kindesalter. Archiv für Kinderheilkunde, 155, 271-284.

Hackzell, G. and Lundmark, C. (1958). Familial juvenile nephronophthisis. Acta paediatrica, 47, 428-440.

Hallman, N. and Hjelt, L. (1959). Congenital nephrotic syndrome. Fournal of Pediatrics, 55, 152-162.

Harris, H. (1967). Genetic aspects of renal disease. In Renal Disease, 2nd ed., pp. 714-735. Oxford, Blackwell Scientific.

Helyer, B. J., and Howie, J. B. (1963). Renal disease associated with positive lupus erythematosus tests in a crossbred strain of mice. Nature (London), 197, 197.

Heptinstall, R. H. (1967). Pathology of the Kidney, pp. 780-785. J. and A. Churchill, London.

Hooft, C., Roels, H., and Herpol, J. (1959). A case of Fanconi's familial juvenile nephronophthisis. Helvetica Paediatrica Acta, 14, 217-233.

Hotchin, J. and Collins, D. N. (1964). Glomerulonephritis and late onset disease of mice following neonatal virus infection. Nature (London), 203, 1357-1359.

Ivemark, B. I., Ljungqvist, A., and Barry, A. (1960). Juvenile nephronophthisis Part II : Histologic and microangiographic study. Acta paediatrica, 49, 480-487.

Kajima, M. and Pollard, M. (1969). Arterial lesions in gnotobiotic mice congenitally infected with LCM virus. Nature (London), 224, 188-190.

Kennedy, G. C. (1957). Effects of old age and over-nutrition on the kidney. British Medical Bulletin, 13, 67-70.

McCrory, W. W., Shibuya, M., and Worthen, H. G. (1966). Hereditary renal glomerular disease in infancy and childhood. $A d-$ vances in Pediatrics, 14, 253-280.

Mangos, J. A., Opitz, J. M., Lobeck, C. C., and Cookson, D. U. (1964). Familial juvenile nephronophthisis. An unrecognized renal disease in the United States. Pediatrics, 34, 337-345.

Mole, R. H. and Watts, R. H. (1971). A simple capillary tube method for the determination of the specific gravity of 25 and 50 $\mu 1$ quantities of wine. Fournal of Clinical Pathology. In press.

Norio, R. (1966). Hereditary in the congenital nephrotic syndrome. Annales Paediatriae Fenniae, 12, Suppl. 27.

Perkoff, G. T. (1964). Familial aspects of diffuse renal disease. Annual Review of Medicine, 15, 115-124.

Royer, P. (1968). Hereditary nephronophthisis. In Nephrology, Vol. 2, pp. 797-802. Ed. by J. Hamburger, G. Richet, J. Crosnier. J. L. Funk-Brentano, B. Antoine, H. Ducrot, J. P. Mery, and H, de Montera. W. B. Saunders, Philadelphia.

Saxton, J. A. and Kimball, G. C. (1941). Relation of nephrosis and other diseases of albino rats to age and to modifications of diet. Archives of Pathology, 32, 951-965.

Seifert, K., Grüttner, R., and Lenz, W. (1960). Über die sogenannte familiäre juvenile Nephronophthise. Frankfurter Zeitschrift für Pathologie, 70, 536-549.

Smith, C. H. and Graham, J. B. (1945). Congenital medullary cysts of the kidneys with severe refractory anaemia. American fournal of Diseases of Children, 69, 369-377. 
Snell, K. C. (1967). Renal disease of the rat. In Pathology of Laboratory Rats and Mice, pp. 105-145. Ed. by E. Cotchin and F. J. C. Roe. Blackwell Scientific Publications, Oxford.

Sokoloff, L. (1965). Musculoskeletal lesions in experimental animals. In The Pathology of Laboratory Animals, pp. 3-18. Ed. by W. E. Ribelin and J. R. McCoy. Charles C. Thomas, Springfield, Illinois.

Sydow, G. von, and Ranström, S. (1962). Familial juvenile nephronophthisis. Acta paediatrica, 51, 561-574. de Vries, M. J. and Vos, O. (1959). Delayed mortality of radiation chimeras: a pathological and hematological study. Fournal of the National Cancer Institute, 23, 1403-1439.

Wigley, R. D. and Couchman, K. G. (1966). Polyarteritis nodosalike disease in outbred mice. Nature (London), 211, 319-320.

Worthen, H. G., Vernier, R. L., and Good, R. A. (1959). Infantile nephrosis. Clinical, biochemical, and morphologic studies of the syndrome. American fournal of Diseases of Chiidren, 98, 731-748. 
be well advised to consult this book first, for it provides a clear indication of what the practising physician should know.

The first chapter gives a straightforward account of how one investigates the genetic component in disease, with an introduction on the interaction of genetic factors and environmental experience. The next five chapters discuss the three main classes of genetically-determined disease-conditions due to chromosome aberrations, conditions due to mutant genes of large effect, and conditions due to numerous genes of individually small effect. These chapters outline the basic principles of medical genetics in a brief but thoroughly readable fashion. The jargon of genetics, which is so often a deterrent, has been reduced to a minimum and the examples are few and well chosen. Certain aspects, such as meiosis and its consequences, are treated more sketchily than they perhaps deserve. However, this is a brief introductory account, and one is impressed less by the omissions than by the quantity of hard fact that it has proved possible to include.

The seventh chapter, and the last of the Lancet articles, is a useful account of the fundamentals of genetic counselling. The author emphasizes the growing importance of antenatal diagnosis by amniocentesis in the prevention of genetic disease, for in an increasing num- ber of conditions selective abortion may enable parents at high risk to have a normal family.

The second to last chapter provides a list of the more common conditions due to mutant genes of large effect. The cautionary paragraph about the pitfalls of wrong diagnosis and genetic heterogeneity which accompanies this list might well be underlined to emphasize the dangers of giving a genetic prognosis on inadequate information. In the final chapter the author discusses present methods and future prospects for the control and prevention of genetically-determined disease. The improved detection of heterozygotes for recessive and $\mathrm{X}$-linked conditions, the importance of intrauterine screening, the theoretical possibility of using genetic linkage for the early diagnosis and control of dominant conditions, and the use of organ transplants in the treatment of biochemical disorders are well considered.

Each chapter is accompanied by references to specific points, and there is a comprehensive index. The book is inexpensive, well produced, and there are few misprints; the only one worth noting is the Lesch-Nyhan eponym which is spelt differently and incorrectly in both the text and the original Lancet article. This little book can be thoroughly recommended to all students of medical genetics as an up-to-the-moment introductory text.

M. A. FERGUSON-SMIth

\section{Corrigendum}

An Inherited Kidney Disease of Mice Resembling Human Nephronophthisis by Mary F. Lyon and E. V. Hulse, March 1971, Vol. 8, pp. 41-48.

The article cited at the end of the section on methods of pathological investigations, p. 42 , column 2 , is by Watts and not by Mole and Watts, and the correct reference is:

Watts, R. H. (1971). A simple capillary tube method for the determination of the specific gravity of 25 and 50 $\mu 1$ quantities of urine. Fournal of Clinical Pathology, 24. (In press.) 